DEPARTMENT OF THE INTERIOR

U.S. GEOLOGICAL SURVEY

\title{
AERIAL GAMMA-RAY CONTOUR MAPS OF REGIONAL SURFACE CONCENTRATIONS OF URANIUM, POTASSIUM, AND THORIUM IN NEW MEXICO
}

By Joseph S. Duval 